\title{
The Determinant of Stock Prices: Evidence on Food and Beverage Companies in Indonesia
}

\author{
Indo Yama Nasarudin ${ }^{1}$, Suhendra ${ }^{2}$, Luthfia Farida Anggraini ${ }^{3}$
}

\begin{abstract}
One aspect that concerns investors in valuing stocks is financial performance. The purpose of this research is to examine the effect of financial performance, firm size, and corporate social responsibility disclosure to the stock price in food and beverage sector companies in Indonesia Stock Exchange. Using a purposive sampling method has done the sample collection method and eleven of eighteen companies, which listed in Indonesia Stock Exchange in the years of 20013-2017, are used as the research samples. The method used in this study was Structural Equation Modeling Partial Least Square (SEM-PLS). The result of the research shows that financial performance, firm size, and corporate social responsibility disclosure affect the stock price. This result implies that the firm should improve the internal factors to increase stock prices.
\end{abstract}

Keywords: financial performance, firm size, social responsibility disclosure, stock price

JEL Classification: G23, G32

\begin{abstract}
Abstrak. Salah satu aspek yang menjadi perhatian investor dalam menilai saham adalah kinerja keuangan Penelitian ini bertujuan untuk mengetahui pengaruh dari Kinerja Keuangan, Ukuran Perusahaan dan Pengungkapan CSR terhadap Harga Saham. Metode Pengambilan sampel menggunakan metode purposive sampling dari delapan belas perusahaan yang terdaftar di Bursa Efek Indonesia pada tahun 20013-2017, hanya sebelas perusahaan yang digunakan dalam sampel penelitian. Dalam melakukan analisis data, peneliti menggunakan teknik analisis data menggunakan metode Partial Last Squeare (PLS). Hasil Penelitian ini menujukkan bahwa kinerja keuangan, ukuran perusahaan, dan pengungkapan corporate social responsibility (CSR) berpengaruh terhadap harga saham. Hal ini berimplikasi bahwa perusahaan harus meningkatkan kualitas faktor internalnya dalam rangka meningkatkan harga saham dari perusahaan.
\end{abstract}

Kata Kunci: kinerja keuangan, ukuran perusahaan, pengungkapan corporate social responsibility, harga saham

\section{How to Cite:}

Nasarudin, I. Y., Suhendra., \& Anggraini, L. F. (2019). The Determinant of Stock Prices: Evidence on Food and Beverage Companies in Indonesia. Etikonomi: Jurnal Ekonomi. Vol. 18 (1): 143 - 154. doi: http//dx.doi.org/10.15408/ etk.v18i1.10987. 


\section{Introduction}

The capital market is one of the main drivers of the world economy, including Indonesia. The development of the financial sector will support economic activity, especially the food and beverage sector in Indonesia. Besides, the prospects of the company in this sector are excellent. In predicting stock prices investors and investment managers carry out fundamental analysis. Fundamental analysis is an analytical method that uses the study of economic conditions, industry and the condition of the company to calculate the fair value of a company's stock. In predicting stock prices investors and investment managers carry out fundamental analysis. The fundamental approach focuses on analyzes to determine the condition of the company's fundamentals that in turn are influenced by economic conditions in general. The condition of the company extracted from a news source (Atkins et al., 2018). Price informativeness about future earnings and investment sensitivity to stock price are lower for high-priced firms (Chan et al., 2017).

Two factors influence stock price movements, namely internal factors, and external factors. This study tries to examine the impact of internal factors on stock price movements in food and beverage companies. The internal factors that will examine in this study are the financial performance, firm size, and Corporate Social Responsibility (CSR) disclosure. The financial performance that will use in this study is the market ratio and the level of profitability. Financial performance is one of the factors used as a reference for an investor in his decision to buy stocks. Some studies have found that financial performance that measured by profitability affects stock prices (Djazuli, 2017; Purnawati, 2016; Pranata \& Pujiati, 2015), although some research find the contrary result (Kabajeh et al., 2012).

Furthermore, another factor that becomes the benchmark of investors is the size of the company. Firm size is an estimating variable that is widely used to explain variations in disclosures in the company's annual report. Firm size reflects the size of the company as seen from the total assets of the company. Several studies have found a positive association between firm size and stock price. The larger the firm size, the higher the price of the stock (Wong, 1989; Raza \& Karim, 2016; Yuliza, 2018). Although, there are also other studies that have found different results. Some studies find a negative influence (Duy \& Phuoc, 2016), and there are those who find no link between firm size and stock price (Davidson III et al., 1993; Shafana et al., 2013).

Investors are not only limited to analyzing the ratio of financial information and firm size, but investors are also expected to see information about the consequences of the company's activities related to the social environment, this shows from the annual report on the CSR disclosure. The implementation of CSR by the company expected that stakeholders have a positive view of the company and attract investors to invest in the company. CSR can be used to mask improper behaviors of the manager (Scholtens \& Kang, 2013; Sun et al., 2010). Several studies have found that there is a positive influence between CSR disclosure and stock prices (Becchetti et al., 2012; Hill et al.,2007; Maqbool \& Zameer, 2018). Although, there are studies that find different results. Some studies find a negative influence between these two factors (Fiori et al., 2015); and there are those who find no link between the two (Yessica et al., 2017; Kim et al., 2014). 
Based on various previous studies, there are still not many studies that examine the factors of company performance, firm size, and CSR disclosure to stock prices. Based on various previous studies, there are still differences in results between studies. Therefore, research on the influence of internal factors on stock prices is still an interesting study. Therefore, this research will contribute significantly to scientific development.

Some studies that have tested the relevance of these factors mostly only use multiple regressions. This research carried out testing using partial least square. This technique is what distinguishes this research from previous studies. In general, this study aims to examine financial performance, firm size, and disclosure of CSR on stock prices in the food and beverage industry in Indonesia.

\section{Methods}

The scope of this study is companies going public in the Food and Beverage Sector listed on the Indonesia Stock Exchange with the period 2013-2017. The researcher focuses on knowing the effect of financial performance, firm size, and disclosure of corporate social responsibility (CSR) on Stock Prices. This research will provide a closing price as a proxy of the stock price. The closing price of a stock is the stock market price that is currently in effect when the stock exchange closes that day. The stock price data used in this study is the stock price determined through the closing price

The study uses secondary data, which uses data in the form of financial statements published by each company listed on the Indonesia Stock Exchange. The population of this study is the Food and Beverage Sector Company that has listed on the Indonesia Stock Exchange, namely as many as 18 Food and Beverage Sector Companies. From this population, the sample was taken using the purposive sampling method. Based on these criteria, there are 11 companies used as research samples.

The method of data analysis in this study uses the Partial Least Square (PLS) method. Partial Least Square Analysis (PLS) is a multivariate statistical technique that performs comparisons between multiple dependent variables and multiple independent variables. PLS is a variant-based SEM statistical method designed to complete multiple regressions when specific data problems occur. The primary purpose of the Partial Least Square method is to predict the relationship of variable $\mathrm{X}$ to the $\mathrm{Y}$ variable and explain the theoretical relationship between the two variables.

The parameter estimates obtained with PLS can categorize into three. First, is the weight estimate that is used to score latent variables? Second, reflects the path estimate (path estimate) that connects latent variables and between latent variables and indicators (loading). Third, related to means and location parameters (regression constant values) for indicators and latent variables. In order to obtain all three of these estimates, PLS uses a 3-stage iteration process, and each iteration stage produces estimates. The first stage produces a weight estimate. Next stage produces estimates for the inner model and outer model. Finally, produces estimates of means and location. The theoretical framework of this research shows in Figure 1. 
Figure 1. Theoretical Framework

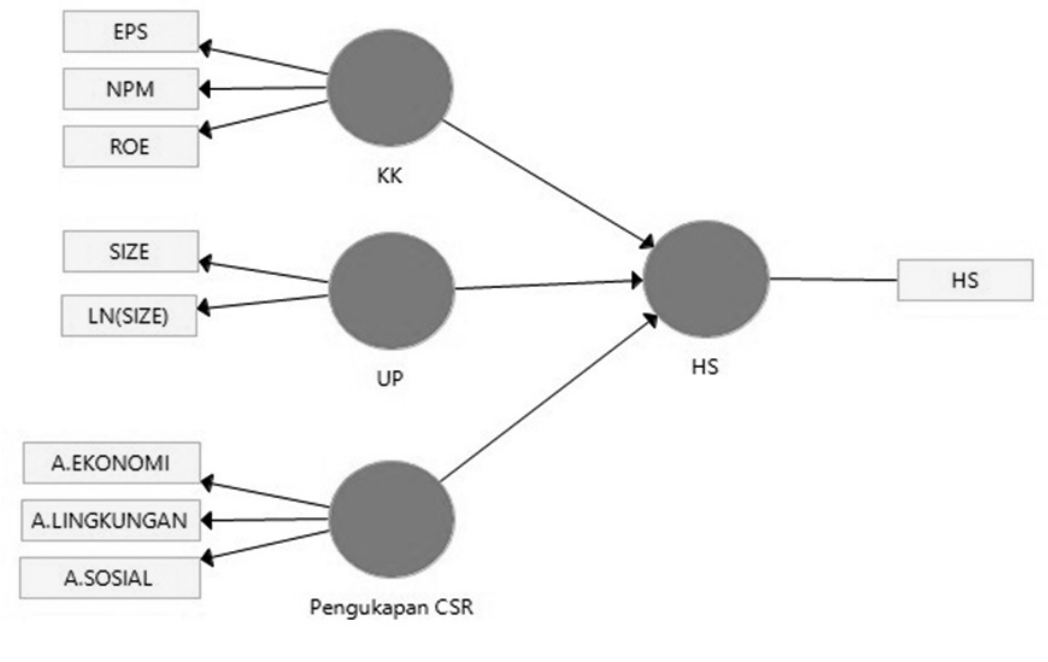

Source: Smart PLS 3

\section{Results and Discussion}

Processing data in this study using PLS techniques. The first step is to determine the sample using the purposive sampling method or the determination of samples with specific considerations in the Food and Beverage Sector companies listed on the Stock Exchange in the period 2013 - 2017 based on the criteria specified in this study. Making descriptive statistics continues the sample selection stage. Descriptive tables explain the variables in the study, including endogenous variables, namely Stock Prices and exogenous variables, namely Financial Performance, Firm size, and Corporate Social Responsibility. The data to be processed is the financial statements for the period 2013-2017. Based on the results of descriptive statistical tests, obtained as many as 55 observational data for sample companies originating from the multiplication of 11 companies with five years from 2013-2017.

Figure 2. Validity

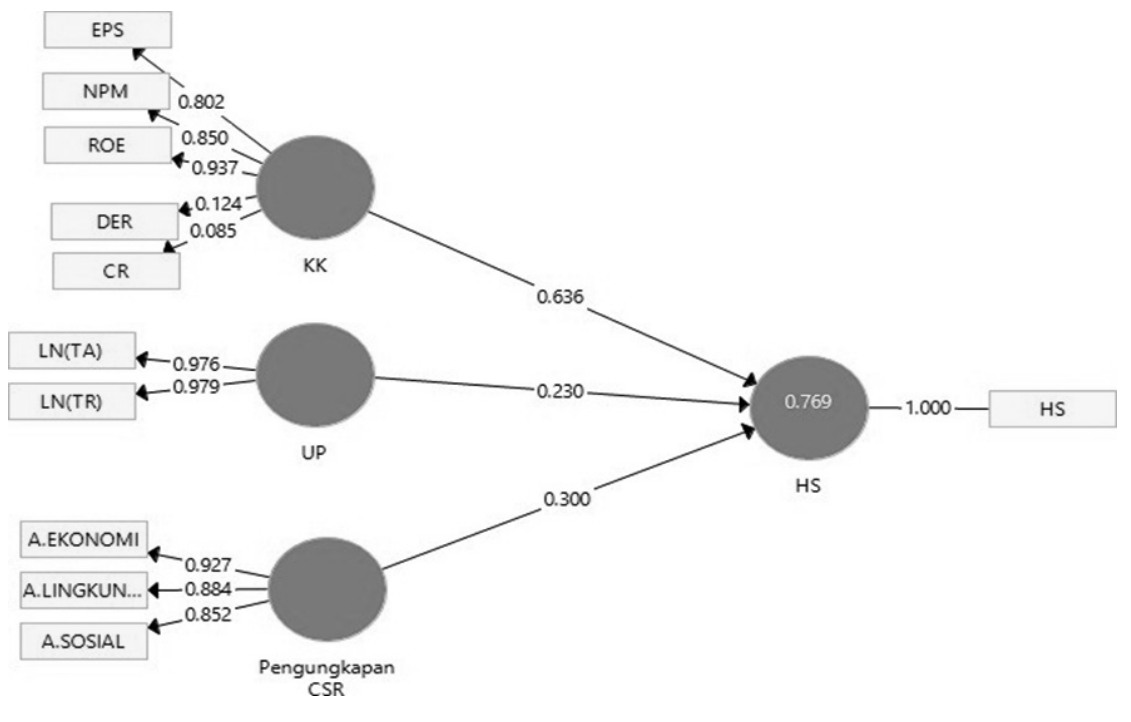

Source: Smart PLS 3 
The validity test is done to determine the ability of the research instrument to measure what should be measured (See Figure 2). The stock price construct only has one manifest variable, namely the stock price so that it can ascertaine that the share price variable can represent the variable price construct. The value of the loading factor of the stock price on the stock price is 1,000 . Then the stock price indicator can be valid in measuring the latent construct because the value of the loading factor is above 0.7. The structure of financial performance has five manifest variables, namely EPS, ROE, NPM, DER and CR. Where the EPS indicator of the financial performance construct variable has a loading factor value of 0.802. The ROE indicator of the construct of financial performance variables has a value of loading factor of 0.937 . The NPM indicator of the construct variable financial performance has a value of loading factor of 0.850 . Then the EPS, ROE, and NPM indicators can be recorded valid in measuring the construct because it has a value of loading factor above 0.7. While the DER indicator has a value of 0.124 loading factor and CR has a value of 0.085 loading factor. The DER and CR indicators have a loading factor below 0.7 , so the two indicators are declared invalid to be continued in the study. The firm size construct has two manifest variables, namely $\operatorname{Ln}(\mathrm{TA})$ and $\mathrm{Ln}$ (TR) where the Ln (TA) indicator of the construct size variable of the company has a value of loading factor of 0.976 .

Figure 3. Path algorithm

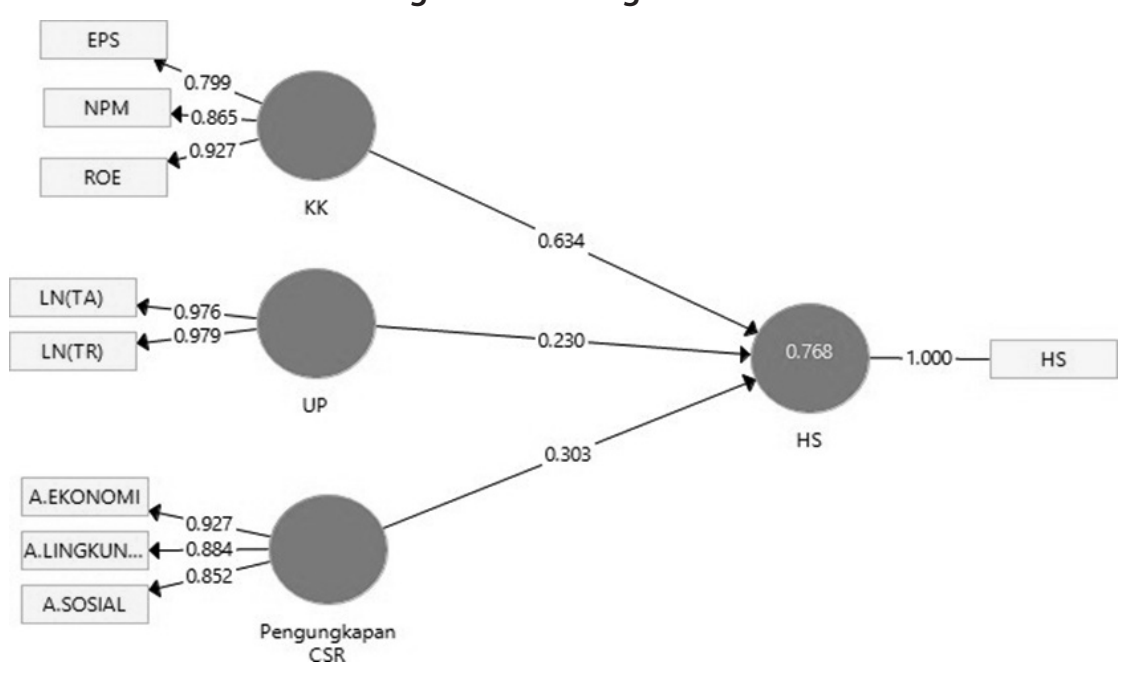

Source: Smart PLS 3

The indicator of $\operatorname{Ln}$ (TR) for construct variables of firm size has a value of loading factor of 0.979 . Then the indicators $\operatorname{Ln}(\mathrm{TA})$ and $\mathrm{Ln}$ (TR) can be recorded valid in measuring the latent construct because the value of the loading factor is above 0.7 . The CSR Disclosure Construct has three manifest variables namely economic aspects, environmental aspects, and social aspects. Where the economic aspect indicator of the construct variable disclosure of CSR has a loading factor value of 0.927 . The environmental aspect indicator for the construct variable disclosure of CSR has a loading factor value of 0.884 . The social aspect indicator of the construct variable disclosure of CSR has a loading factor value of 0.852. Then indicators of economic aspects, environmental aspects, and social aspects can 
be recorded valid in measuring latent constructs because the value of the loading factor is above 0.7 .

Based on the result, two indicators of Financial Performance namely DER and CR have a loading factor value below 0.7 so that the DER and CR indicators eliminated. The Path Algorithm shows in Figure 3. From Figure 3, it can conclude that indicators that have values above 0.7 are valid and ideal indicators in measuring latent constructs and this research can continue.

Table 1. Square Root of AVE

\begin{tabular}{lcc}
\hline \multicolumn{1}{c}{ Construct } & AVE & Square Root of AVE \\
\hline Stock price & 1,000 & 1 \\
Financial Performance & 0,749 & 0,865 \\
Social Responsibility Disclosure & 0,956 & 0,977 \\
Firm Size & 0,789 & 0,888 \\
\hline
\end{tabular}

Source: Smart PLS 3

The method used to assess discriminant validity is to compare the AVE roots for each construct with other constructs in the model. Based on Square Root of AVE in Table 1 shows that the maximum correlation of the construct of the Stock Price to other constructs is 1,000 . The Root Squeeze of Ave is 1,000, and then the construct of the Stock Price has valid discriminant validity. The maximum correlation from the construct of Financial Performance to other constructs is 0.749 , and its Root of Ave Square is 0.865, then the Financial Performance construct has valid discriminant validity. The maximum correlation from the construct of Firm size to other constructs is equal to 0.956, and its Root of Ave Square is 0.977 , then the Firm size construct has valid discriminant validity. The maximum correlation of the CSR Disclosure construct towards other extracts is 0.789 , and its Root of Ave Square is 0.888 , then the Stock Price construct has valid discriminant validity. From the four constructs, it can conclude that the discriminant validity of each variable in this study fulfills.

After testing the validity, a reliability test can show from the results of Cronbach's Alpha, composite reliability and Average Variance Extracted (AVE). Acceptable Cronbach's Alpha and composite reliability values are $>0.6$, and the practical value of Average Variance Extracted (AVE) is $>0.5$.

Based on the Path Coefficient in Table 2, it can see that the value of Cronbach's Alpha Stock price is 1,000 , Financial Performance is 0.859 , Firm size is 0.958 , and CSR Disclosure is 0.893 , it can conclude that the lower limit of the reliability of the three constructs above 0.7 could be said to be reliable and acceptable. If seen from the value of Composite Reliability Share price is 1,000 , Financial Performance is 0.899 , Firm size is 0.977 and Disclosure of CSR is 0.918 , it can conclude that the real value of the reliability of the three constructs having a value above 0.7 can be said to be reliable and acceptable. 
Table 2. Path Coefficients

\begin{tabular}{lcccc}
\hline & $\begin{array}{c}\text { Cronbach's } \\
\text { alpha }\end{array}$ & Rho Alpha & $\begin{array}{c}\text { Composite } \\
\text { Reliability }\end{array}$ & $\begin{array}{c}\text { Average Variance } \\
\text { Extracted }\end{array}$ \\
\hline Stock price & 1.000 & 1.000 & 1.000 & 1.000 \\
Financial Performance & 0.832 & 0.859 & 0.899 & 0.749 \\
Social Responsibility Disclosure & 0.867 & 0.893 & 0.918 & 0.789 \\
Firm Size & 0.954 & 0.958 & 0.977 & 0.956 \\
\hline
\end{tabular}

Source: Smart PLS 3

Furthermore, the value of Average Variance Extracted (AVE) from Table 3 based on three constructs, namely stock prices. The AVE value of the three constructs has a value greater than 0.5 , so the convergent validity measurement of this study is good, and the latent variable can explain the variance from, valid and acceptable. So this research can be continued.

The $\mathrm{R}^{2}$ value is used to measure the level of variation in changes in the independent variable on the dependent variable. The higher the value of $\mathrm{R}^{2}$ means the better the prediction model of the proposed research model. Based on Table 3, Financial Performance, Firm size, and Disclosure of CSR can explain the variability of constructs of Stock Prices of 0.768 or $76.8 \%$ (Value of $\mathrm{R}^{2}$ ), the remaining or $23.2 \%$ explained by other constructs which not hypothesized in research.

Table 3. Coefficient of Determination $\left(R^{2}\right)$

\begin{tabular}{ccc}
\hline & R-Square & R-Square Adjusted \\
\hline Stock price & 0.768 & 0.754 \\
\hline
\end{tabular}

Source: Smart PLS 3

The purpose of the GoF calculation is to validate the overall model. The GoF index is a single measurement used to validate the combination of performance from the measurement model and the structural model. PLS does not provide a special menu for calculating GoF. GoF values stretch between 0-1 with interpretations of values is 0.1 (small GoF), 0.25 (moderate GoF), and 0.36 (large GoF). The formula can measure the GoF PLS model:

$$
\begin{array}{ll}
\mathrm{GoF} & =\sqrt{\operatorname{Com} x R^{2}} \\
\text { Information: } & \\
\mathrm{Com} & =\text { mean of communalities } \\
\mathrm{R}^{2} & =\text { mean of } \mathrm{R}^{2} \\
\mathrm{GoF} & =\sqrt{0.932 \times 0.768} \\
\mathrm{GoF} & =0.715
\end{array}
$$


From the above calculations, it can conclude that this research model is valid and has good performance. In the PLS the statistical test of each hypothesized relationship is carried out using a simulation. In this case, the bootstrap method performs on the sample Bootstrap testing is also intended to minimize the problem of research data abnormalities.

Figure 4.Path Bootstrapping

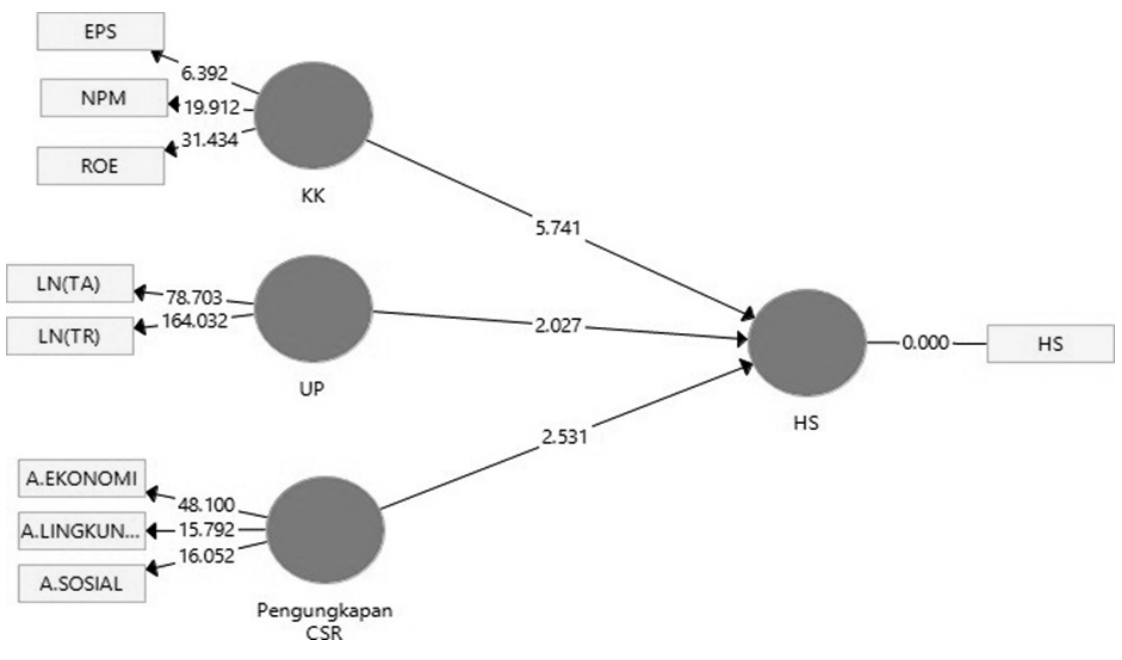

Source: Smart PLS 3

Table 4 shows the total effect of the variables. The relationship between financial performance and stock prices shows a significant value. The original sample estimate value is positive, which is 0.634; the direction of the relationship between Financial Performance and Stock Price is positive. This result means that the better the financial performance of the company, the better the stock price. It can show in Figure 4; the ROE indicator has the most significant value compared to the value of the other indicators that is equal to 31.434 .

Table 4. Total Effect

\begin{tabular}{lccccc}
\hline & $\begin{array}{c}\text { Original } \\
\text { Sample }\end{array}$ & $\begin{array}{c}\text { Sample } \\
\text { Mean }\end{array}$ & $\begin{array}{c}\text { Stand. } \\
\text { Dev. }\end{array}$ & t-Stat. & P-Value \\
\hline Financial Performance ---> Stock price & 0.634 & 0.626 & 0.110 & 5.741 & 0.000 \\
CSR Disclosure ---> Stock price & 0.303 & 0.287 & 0.120 & 2.531 & 0.012 \\
Firm Size ---> Stock price & 0.230 & 0.248 & 0.113 & 2.027 & 0.043 \\
\hline
\end{tabular}

Source: Smart PLS 3

Table 4 also shows that ROE has a dominant influence in representing the construct of Financial Performance on Stock Prices in the food and beverage sector companies for the period 2013-2017. The higher the ROE value means the ROE indicator is more representative of the conception of Financial Performance. From the descriptive analysis shows that the average value of ROE growth in the food and beverage sector during the period 2013-2017 has a value of $23.30 \%$, it concludes that the ROE growth rate in food and beverage sector 
companies is reasonable because it is above $15 \%$. ROE describes the company's ability to manage capital in generating profits. If the ROE value is high, the investor will judge that the company can generate high profits with the equity it has, so that it will be able to prosper shareholders. This result is consistent with Vijayakumar (2010), Pranata \& Pujiati (2015), and Purnawati (2016) that also found the relationship between financial performance and stock prices. However, this research is contradicted with Kabajeh et al., (2012), which found there is no relationship between financial performance and stock prices.

The relationship between firm size and Stock Price shows a significant value. The direction of the relationship between Firm size and Stock Price is positive, which means that the bigger the company, the better the Stock Price. Total assets and total revenue reflect the variable firm size. This result shows that total revenue has a dominant influence in representing the construct of Firm size to Stock Prices in the food and beverage sector companies for the period 2013-2017. The higher the total revenue value, the more represents the extract of Firm size. This research is consistent with some of the previous research (Wong, 1989; Raza \& Karim, 2016; Yuliza, 2018). The opposite result of this research also found, which there is a negative relationship between firm size and stock returns (Duy \& Phuoc, 2016). Davidson III et al., (1993), and Shafana et al., (2013) also conclude that there is no relation in the economy between firm size and stock return.

From the descriptive analysis shows that the average value of total revenue growth in the food and beverage sector during the period 2013-2017 has a value of 15.18. It concludes that the growth rate of total revenue in the food and beverage sector is reasonable because it has increased decrease, but the value is still close to the average of 15.02. Firm size describes the extent of the company that can cause stock prices to move up. If the size of the company has substantial total revenue, it will attract investors to invest in food and beverage sector companies.

The relationship between CSR Disclosure and the Stock Price shows a significant value. The direction of the relationship between CSR Disclosure and the Stock Price is positive, which means that the company's social responsibility reports will increase well too. Indicators of economic aspects, environmental aspects, and social aspects reflect CSR variables. Figure 4 show that economic aspect indicators have a value of 48,100 . This value is the most substantial value compared to the value of other indicators. This result shows that the economic aspect has a dominant influence in representing the CSR construct towards the Stock Price in the food and beverage sector company. The higher the value of the economic aspect, the more represent the CSR construct. From the descriptive analysis shows that the average value of total revenue growth in the food and beverage sector during the period 2013-2017 has a value of 0.20 . It concludes that food and beverage sector companies are very concerned about the economic aspects of CSR disclosure.

This result is consistent with some studies that also found the relationship between corporate social responsibility (CSR) of the companies and the stock prices (Becchetti et al. 2012; Hill et al., 2007; Maqbool \& Zameer, 2018). Fiori et al., (2015) found the opposite result. They found that excellent social performance has a negative influence on stock prices. 
Yessica et al., (2017) show that the CSR disclosure did not have a relationship to the risk of the company stock price. Kim et al., (2014) indicate that the high or low CSR reporting scores of a company does not affect the size of the risk of stock price crash at the companies.

Besides those factors that had discussed in this study, stock prices also influenced by external factors. One of the factors that affect stock prices is an exchange rate. Tang \& Yao (2018) conclude that there is a link between exchange rates and stock prices through the inner-financial structure. Caporale et al., (2014), Roberado et al., (2016) also found the relationship between exchange rate and stock prices. Oil prices also one of the external factors that influence the stock prices (Smyth \& Narayan, 2018; Wei \& Gun, 2017; Wen et al., 2018; Zheng \& Su, 2017). Macroeconomic fundamentals also one of the factors that affect stock prices (Hussainey \& Ngoc, 2009).

\section{Conclusion}

This study aims to determine the effect of Financial Performance, Firm size, and Disclosure of CSR on Stock Prices. The EPS, ROE, and NPM ratios measure the performance variable. Based on the results of the study, it can conclude as follows that financial performance reflected by the EPS, ROE and NPM ratios has a significant influence on stock prices. This result shows that the better the financial performance, the higher the price of shares traded. The size of the company reflected by total assets and total revenue has a significant influence on stock prices. This fact shows that the wider the company, the higher the price of shares traded. Disclosure of CSR reflected by economic aspects, environmental aspects, and social aspects has a significant effect on stock prices. This fact shows that the wider the disclosure of the company's image to the community, the higher the price of shares traded1. Financial performance reflected by the EPS, ROE and NPM ratios has a significant influence on stock prices. The better the financial performance, the higher the price of shares traded.

\section{References}

Atkins, A., Niranjan, M., \& Gerding, E. (2018). Financial News Predicts Stock Market Volatility Better Than Close Price. The Journal of Finance and Data Science, 4(2), 120 137. https://doi.org/10.1016/j.jfds.2018.02.002

Becchetti, L., Ciciretti, R., Hasan, I., \& Kobeissi, N. (2012). Corporate Social Responsibility and Shareholder's Value. Journal of Business Research, 65(11), 1628-1635.

Caporale, G. M., Hunter, J., \& Ali, F. M. (2014). On the Linkages Between Stock Prices and Exchange Rates: Evidence from the Banking Crisis of 2007-2010. International Review of Financial Analysis, 33, 87-103. https://doi.org/10.1016/j.irfa.2013.12.005

Chan, K., Li, F., Lin, J.-C., \& Lin, T.-C. (2017). What do Stock Price Levels Tell us About the Firms. Journal of Corporate Finance, 46, 34-50. https://doi.org/10.1016/j. jcorpfin.2017.06.013

Davidson III, W., Ferris III, K., \& Reichenstein III, W. (1993). A Note of the Relationship Between Firm Size and Return in the Electric Utility Industry. Journal of Accounting, Auditing, and Finance, 8(3), 193-202. https://doi.org/10.1177/0148558X9300800301 
Djazuli, A. (2017). The Relevance of Leverage, Profitability, Market Performance, and Macroeconomic to Stock Prices. EKOBIS, 22(2), 112-122.

Duy, N. T., \& Phuoc, N. P. H. (2016). The Relationship Between Firm Sizes and Stock Returns of Service Sector in Ho Chi Minh City Stock Exchange. Review of European Studies, 8(4), 210-219. https://doi.org/10.5539/res.v8n4p210

Fiori, G., di Donato, F., \& Izzo, M. F. (2015). Corporate Social Responsibility and Stock Prices: a Study on the Italian Market. Corporate Ownership \& Control, 12(2), 600-609.

Hill, R. P., Ainscough, T., Shank, T., \& Manullang, D. (2007). Corporate Social Responsibility and Socially Responsible Investing: A Global Perspective. Journal of Business Ethics, $70(2), 165-174$.

Hussainey, K., \& Ngoc, L. K. (2009). The Impact of Macroeconomic Indicators on Viatnamese Stock Prices. The Journal of Risk and Finance, 10(4), 321-332. https://doi. org/10.1108/15265940910980632

Kabajeh, M. A. M., Al Nuaimat, S. M. A., \& Dahmash, F. N. (2012). The Relationship Between the ROA, ROE, and ROI Rations with Jordanian Insurance Public Companies Market Share Prices. International Journal of Humanities and Social Sciences, 2(11), 1011-1020.

Kim, Y., Li, H., \& Li, S. (2014). Corporate Social Responsibility and Stock Price Crash Risk. Journal of Banking and Finance, 43, 1-13. https://doi.org/10.1016/j. jbankfin.2014.02.013

Maqbool, S., \& Zameer, M. N. (2018). Corporate Social Responsibility and Financial Performance: An Empirical Analysis of Indian Banks. Future Business Journal, 4(1), 84-93. https://doi.org/10.1016/j.fbj.2017.12.002

Pranata, D., \& Pujiati, D. (2015). The Effect of Liquidity, Profitability, Sales Growth, and Dividend Policy on Stock Prices After the Implementation of IFRS. The Indonesian Accounting Review, 5(2), 169-178. https://doi.org/10.14414/tiar.v5i2.559

Purnawati, I. G. A. (2016). The Effect of Capital Structure and Profitability on Stock Price: Study of The Manufacturing Sector in Indonesia Stock Exchange. International Journal of Business, Economics, and Law, 9(1), 10-16.

Raza, S. A., \& Karim, M. Z. A. (2016). Do Liquidity and Financial Leverage Constrain the Impact of Firm Size and Dividend Payouts on Share Price in Emerging Economy. Journal of Finance and Economic Research, 1(2), 71-86. https://doi.org/10.20547/jfer.1601201

Roberado, J. C., Rivera-Castro, M. A., \& Ugolini, A. (2016). Downside and Upside Risk Spillovers Between Exhange Rates and Stock Prices. Journal of Banking and Finance, 62, 76-96. https://doi.org/10.1016/j.jbankfin.2015.10.011

Scholtens, B., \& Kang, F. C. (2013). Corporate Social Responsibility and Earnings Management: Evidence from Asian Economies. Corporate Social Responsibility, 20(2), 95-112.

Shafana, M. A. C. N., Rimziya, F., \& Jariya, A. M. I. (2013). Relationship Between Stock Returns and Firm Size, and Book-to-Market Equity: Empirical Evidence from Selected Companies Listed on Milanka Price Index in Colombo Stock Exchange. Journal of Emerging Trends in Economics and Management Sciences, 4(2), 217-225. 
Smyth, R., \& Narayan, P. K. (2018). What do We Know About Oil Prices and Stock Returns. International Review of Financial Analysis, 57, 148-156. https://doi.org/10.1016/j. irfa.2018.03.010

Sun, N., Salama, A., Hussainey, K., \& Habbash, M. (2010). Corporate Environmental Disclosure, Corporate Governance and Earnings Management. Managerial Auditing Journal, 25(7), 697-700.

Tang, X., \& Yao, X. (2018). Do Financial Structures Affect Exchange Rate and Stock Price Interaction? Emerging Markets Review, 34, 64-76. https://doi.org/10.1016/j. ememar.2017.10.004

Vijayakumar, A. (2010). Effect of Financial Performance on Share Prices in the Indian Corporate Sector: An Empirical Study. Management and Labour Studies, 35(3), 369381. https://doi.org/10.1177/0258042X1003500304

Wei, Y., \& Gun, X. (2017). Oil Price Shocks and China’s Stock Market. Energy, 140(1), 185-197. https://doi.org/10.1016/j.energy.2017.07.137

Wen, X., Bouri, E., \& Roubaud, D. (2018). Does Oil Product Pricing Reform Increase Returns and Uncertainty in the Chinese Stock Market? The Quarterly Review of Economics and Finance, 68, 23-30. https://doi.org/10.1016/j.qref.2017.08.003

Wong, K. A. (1989). The Firm Size Effect on Stock Returns in a Developing Stock Market. Economics Letters, 30(1), 61-65. https://doi.org/10.1016/0165-1765(89)90157-2

Yessica, H. M., Ganis, S. E., \& Erwin, S. (2017). The Role of Corporate Social Responsibility Disclosure toward Company Stock Price Crash Risk. RJOAS, 8(68), 197-208. https:// doi.org/10.18551/rjoas.2017-08.23

Yuliza, A. (2018). The Effects of Earning per Share and Firm Size to Stock Price LQ45 Company Listed in Indonesian Securities. International Journal of Engineering \& Technology, 7(4), 247-249.

Zheng, X., \& Su, D. (2017). Impact of Oil Price Shocks on Chinese Stock Market Liquidity. International Review of Economics and Finance, 50, 136-174. https://doi.org/10.1016/j. iref.2017.03.021 